\title{
Sediment Yield and Sand Erosion Model through Arc SWAT and SPSS-14 Software for Sand Mine Site in Rajasthan
}

\author{
Sangeeta Choudhary, Prem Choudhary
}

\begin{abstract}
Sand mining activities are considered as a profitable venture in present scenario of development, but these activities can cause a great trouble to environment. There are many factors which affects sand erosion of particular area. The main purpose of the study is to establish a mathematical model for sand mining site of the study area to identify the factors affecting the sediment yield and erosion of the sand at mining site. Kosana Sand mining site on Mithri tributary at Luni River near Pipar tehsil in Jodhpur, Rajasthan was selected. Sediment yield is workout based on the observations and calculations of ArcSWAT model. A mathematical model of study area is developed by using SPSS-14 software. Data of surface runoff, sediment yield and erosion are used to formulate a mathematical model. It is found that both erosion and sediment yield are related to surface runoff with cubic equation with value of coefficient of determination $\left(R^{2}\right)$ 0.944. The sediment yield at drainage location depends on the surface runoff of the watershed.
\end{abstract}

Keywords: Sand Mining, Erosion, Surface runoff, Sediment yield, ArcSWAT.

\section{INTRODUCTION}

Nature of the most of the rivers of the world has been changed due to disorganized mining of sand and gravel from river bed is the most eager as this activity threatens the survival of the river ecosystem [1], [2]. The pace of ecological degradation and complication of natural processes have been increased due to industrialization, agricultural activities and intense pace of urbanization. Sand is an essential mineral for our society which is required to manufacture concrete structure, roads, bricks, glass, sand papers etc. Sand mining activities are considered as a profitable venture in the present scenario of development, but these activities can cause a great trouble to environment. Demand for sand continues to grow in present scenario. It is difficult to transport the huge quantity of sand for long distance and it is not also economical because cost of construction project can be highly increased due to transportation cost. Therefore construction companies desire to have it from the close areas. The ecological consequences of such mining can be serious. Environmental problem occurs when the rate of withdrawal of sand, gravel and other

Revised Manuscript Received on March 5, 2020.

Sangeeta Choudhary, Techno India NJR Institute of Technology, sangeeta27apr@gmail.com

Prem Choudhary, Bharat Electronics Limited material exceeds the rate of replenishment at which natural processes produce these materials. Mining activity and development have become complimentary to each other. As an effect of developmental activities noticeable bad-effects of the environmental deprivation are clear and give signals of the alarming situation. Therefore an admissible betterment of area concerning mining of mineral wealth vis-a-vis protection of environment is the ultimate solution for development of mankind [3]. The demand of river sand as a source of construction material has increased due to fast development in recent past decades. This has resulted in rapidly increasing of river sand mining activities in all part of the world. Rajasthan, which is presently considered, an under-developed state in India. Central as well as state government is now launching various infrastructure projects in the state. These projects need a huge quantity of sand. The huge demand of the sand has increased sand mining activities in whole Rajasthan.

Environmental problem occurs when the rate of withdrawal of sand, gravel and other material exceeds the rate of replenishment at which natural processes produce these materials. Mining activity and development have become complimentary to each other. As an effect of developmental activities noticeable bad-effects of the environmental deprivation are clear and give signals of the alarming situation. Therefore an admissible betterment of area concerning mining of mineral wealth vis-a-vis protection of environment is the ultimate solution for development of mankind. So, it is the need of the time to determine a safe limit for withdrawal of sand quantity and other material from the riverbed in a particular reach of river.

\section{A. Location of Study Area}

The location of study area is situated at Mithri River which is branch of Luni River in Rajasthan. The region is enclosed in survey of India Toposheet no. 45 F/11

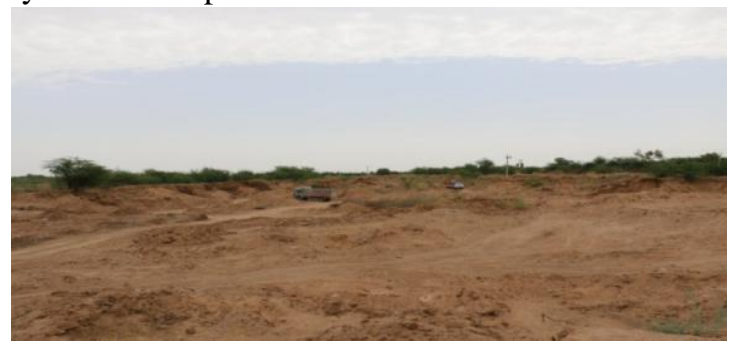

Fig 1: Mine Site at Mitheri River

Published By: 


\section{METHODOLOGY}

Thus ArcSWAT can be the good modeling tool related to water and sediment yield. There are several legal and illegal sand mining sites under operation in dried river beds of India. Government authorities allot sand mines to the mining contractors keeping in view Environmental Impact Assessment (EIA) guidelines. ArcSWAT has the capability to process and display data which have spatial components. The spatial information component gives the information about the location in real world. ArcSWAT has the capability to store various data into layers of the map [4]. This software is widely used by hydrologist to find out the sediment yield of the reservoirs. An attempt has been made in this study to apply the same technique to find out the sediment yield in order to find out the rate of replenishment. Kosana Sand Mining Site on Mithri tributary on Luni River near Pipar tehsil was selected for the study purpose. The main reason for selecting this site is that, it is very less exploited sand mining site from which very less sand was removed at the time of starting study.

All the area nearby the sand mining site was studied and using ArcSWAT software appropriate watershed developing was attempted. Making correct watershed of the area was very important for the study as it is the catchment area of land where water balance takes place. This is the area where water is received in the form of precipitation and watershed is prepared in such a way that it completely drains off from the point on the tributary where sand mining site is located. Water causes runoff of the watershed and draining will bring sediment along with the running water of watershed. The watershed making process provides the boundary of the study and synthetic reach provides the course of the tributary. This course was further validated based on actual visual survey. Further calibrations are incorporated in the input data provided to the ArcSWAT to match field conditions. The main input used for making watershed in ArcSWAT is the Digital Elevation Model (DEM) data. Many DEM data of various resolutions from the available satellite data of NASA and ISRO were tried, to select the most appropriate DEM data that is compatible to ArcSWAT at one hand and gives appropriate result at other hand in the form of watershed and reach or course of the river. In this process the geographic coordinate system and projected coordinate system was studied and its importance in GIS was well understood. After generating watershed and reach or course of the Mithri tributary drained at sand mining site spatially distributed land use and soil data was required. Many freely available land use land practices data and soil type databases were tried, but were not found compatible with ArcSWAT. So, National Bureau of Soil Survey and Land Use Practices (NBSSLUP) Udaipur centre was approached. The digitized spatially distributed data of Land Use and Land Cover (LULC) and Soil Types were collected and then clipped as per the watershed of the study Area. The required look up tables was created for LULC and soil types to generate appropriate thematic layers of the map ready for overlaying. Many soil types were studied and based on the sample testing of soil samples in the lab missing parameters were filled in the soil database used to create soil thematic layer in the map. Next important data required was the weather data which included spatially distributed precipitation, temperature, wind, relative humidity and solar radiance was required. The weather data was required because the hydrologic cycle is climate driven, which provides moisture and energy inputs to control the water balance. In this process with the help of various published papers and documentation of ArcSWAT it was understood that most accurate and compatible data is available at global weather repository. The data of the surrounding climate stations of study Area watershed was collected in the form of text editor readable data which are readable by ArcSWAT software. These data were the daily data of precipitation, temperature, wind, relative humidity and solar radiance of the nearby weather stations for 21 years. Complete data of simulation period was collected and integrated in ArcSWAT modeling simulation.

The results of the simulation were in the form of database files. Database files were opened with suitable software and output were thoroughly analyzed in order to comprehend the study results. The Sediment delivery ratio was calculated as per the Williams (1977) mathematical model which is correlated with drainage area, relief-length ratio, and runoff curve numbers of the watershed. The Erosion corresponding to sediment yield was worked out as per the Williams (1997) equation of Sediment Delivery Ratio [5], [6]. The various parameters like drainage area of watershed difference of the average elevation of watershed and average elevation of the sand mining area, the length of watershed and the long term average SCS curve number was computed using the ArcGIS software[7].

\section{RESULTS AND DISCUSSION}

Based on the observations and calculations of Arc SWAT model mathematical equations between input environmental factors and desired output factor that is sediment yield is worked out. Williams (1977) developed a model based on the sediment yield data for 15 Texas basins. The model is expressed as follows:

The Sediment Delivery Ratio (SDR) ) formula by Williams (1977) :

$\mathrm{SDR}=1.366 \times 10^{-11}(\mathrm{DA})^{-0.0998}(\mathrm{ZL})^{0.3629}(\mathrm{CN})^{5.444}$ is

calculated for Kosana watershed is 0.102564 .

Where DA - Drainage Area

ZL - Relief-length Ratio

$\mathrm{CN}$ - Runoff Curve Number

The erosion can be calculated by $\mathrm{E}=\mathrm{SY} / \mathrm{SDR}$

Sediment yield and Surface Runoff from SWAT simulation result and calculated Erosion values are mentioned in table I. 
Table I: Sediment Yield, Surface Runoff data and empirically calculated Erosion Data of the watershed of the study area

\begin{tabular}{|c|c|c|c|}
\hline Year & $\begin{array}{c}\text { Surface } \\
\text { mm }\end{array}$ & $\begin{array}{c}\text { Sediment } \\
\text { Yield in } \\
\text { tons/ha }\end{array}$ & $\begin{array}{l}\text { Erosion in } \\
\text { tons/ha }\end{array}$ \\
\hline 1997 & 80.453 & 9.418 & 91.82559 \\
\hline 1998 & 45.133 & 6.821 & 66.50482 \\
\hline 1999 & 26.787 & 4.388 & 42.78304 \\
\hline 2000 & 32.031 & 5.734 & 55.90656 \\
\hline 2001 & 101.982 & 18.974 & 184.9967 \\
\hline 2002 & 23.606 & 3.32 & 32.37003 \\
\hline 2003 & 410.629 & 118.668 & 1157.014 \\
\hline 2004 & 20.479 & 3.538 & 34.49553 \\
\hline 2005 & 6.725 & 0.547 & 5.333255 \\
\hline 2006 & 1.091 & 0.267 & 2.603253 \\
\hline 2007 & 2.954 & 0.312 & 3.042003 \\
\hline 2008 & 162.917 & 45.639 & 444.9807 \\
\hline 2009 & 102.81 & 44.576 & 434.6164 \\
\hline 2010 & 34.188 & 4.436 & 43.25104 \\
\hline 2011 & 128.435 & 14.251 & 138.9474 \\
\hline 2012 & 24.634 & 2.321 & 22.62977 \\
\hline 2013 & 164.076 & 39.205 & 382.2491 \\
\hline 2014 & 8.182 & 0.77 & 7.507508 \\
\hline & & & \\
\hline
\end{tabular}

Regression analysis for Yield:

Regression analysis is done with the help of SPSS 14 (Software for Statistical Analysis). The calculated values of runoff, sediment yield and erosion are already given in the table I. The dependent variable Sediment Yield is denoted by $\mathrm{Y}_{1}$ and independent variable Surface Runoff is denoted $\mathrm{X}$. The analyzed data are given in table II and graph 1 .

Table II: Model Summary and Parameter Estimates

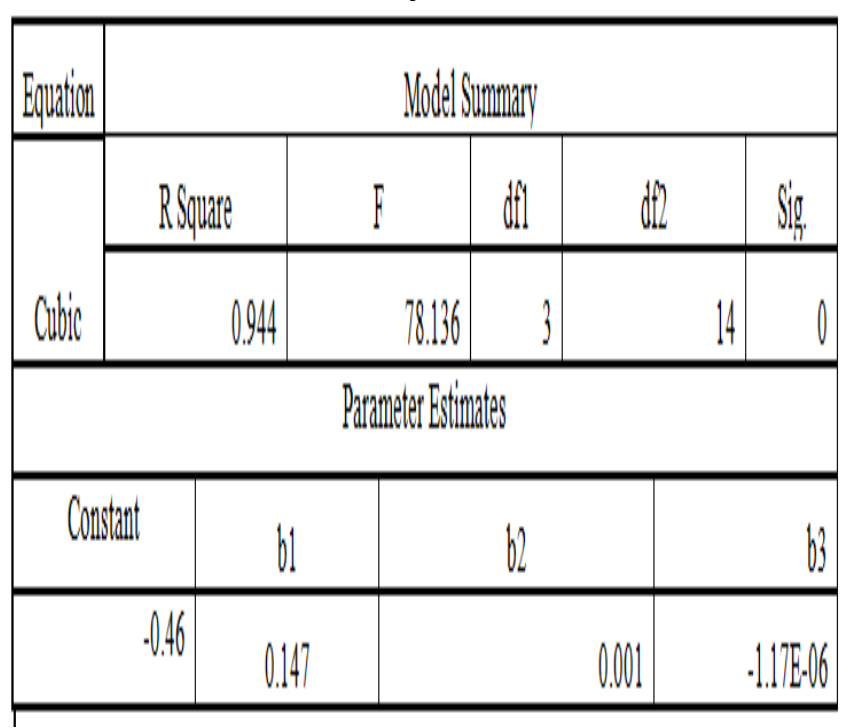

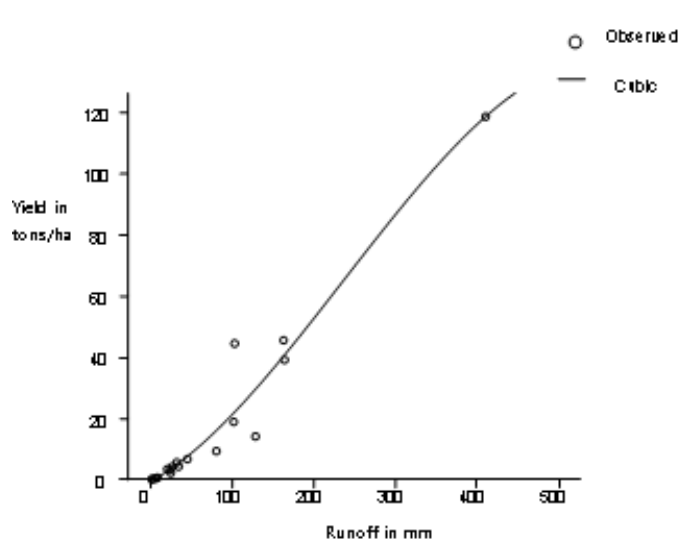

Graph1: Mathematical model curve of Sediment yield depending on surface runoff of the watershed

F-Test:

$\mathrm{H} 0: \beta 1=\beta 2=0$ against $\mathrm{H1}$ : not all $\beta \mathrm{k}=0:(\mathrm{k}=1,2,3)$

Model table gives the value of calculated ' $F$ ' $=78.136$

Fn-k-1, $\alpha=3.3439$ (From standard tables; df1=3 and df2=14 and $\alpha=0.05$ )

Hence FCAL $>$ Fk, Fn-k-1, $\alpha$

Hence, reject $\mathrm{H} 0$ at $\alpha=0.05$ level of significance

Thus the estimated multiple regression analysis equation for Yield can be expressed as:

$$
\mathrm{Y} 1=0.147 \mathrm{X}+0.001 \mathrm{X} 2-0.00000117 \mathrm{X} 3
$$

Where: $\mathrm{Y} 1=$ Sediment Yield in tons/ha

$$
\mathrm{X}=\text { Surface Runoff in } \mathrm{mm}
$$

\section{Interpretation:}

Value of coefficient of determination (R2) is 0.944, it indicates that dependency of dependent variable "Yield" is about $94.4 \%$ on runoff and remaining $5.6 \%$ is due to other variables. Hence estimated equation can be used for calculation of yield.

\section{Regression analysis for Erosion}

The dependent variable Erosion is denoted as $\mathrm{Y}_{2}$ and independent variable Surface Runoff is denoted as $\mathrm{X}$. The analyzed data are given in table III and graph 2.

Table III: Model Summary and Parameter Estimates

\begin{tabular}{|c|r|c|r|r|r|}
\hline \multirow{2}{*}{ Equation } & \multicolumn{6}{|c|}{ Model Summary } \\
\hline \multirow{6}{*}{ Cubic } & R Square & F & df1 & df2 & Sig. \\
\cline { 2 - 6 } & .944 & 78.136 & 3 & 14 & .000 \\
\hline \multicolumn{5}{|c|}{ Parameter Estimates } \\
\hline Constant & \multicolumn{2}{|c|}{ b1 } & b2 & b3 \\
\hline & -4.490 & 1.435 & .008 & $-1.14 E-005$ \\
\hline
\end{tabular}




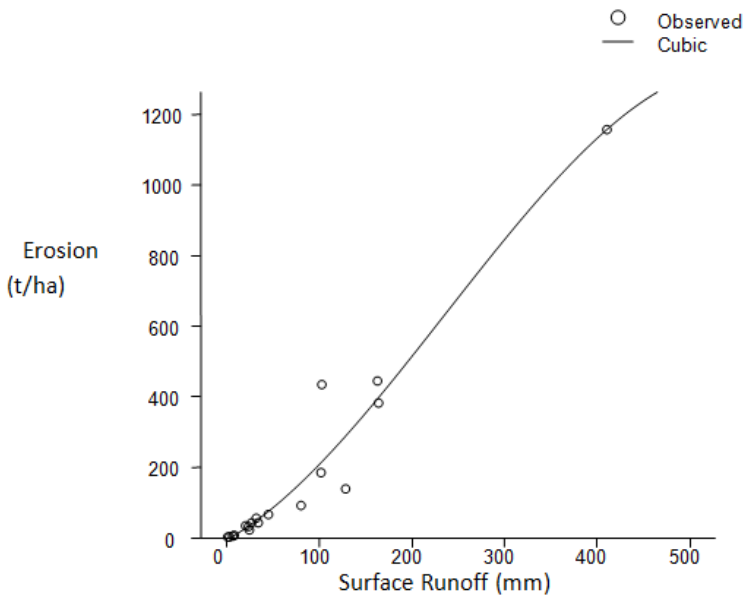

Graph 2: Mathematical model curve of Erosion depending on surface runoff of the watershed

F-Test:

$\mathrm{H}_{0}: \beta_{1}=\beta_{2}=0$ against $\mathrm{H}_{1}$ : not all $\beta_{\mathrm{k}}=0:(\mathrm{k}=1,2,3)$

Model table gives the value of calculated ' $\mathrm{F}^{\prime}=78.136$

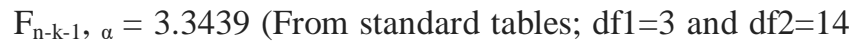
and $\alpha=0.05$ )

Hence $\quad \mathrm{F}_{\mathrm{CAL}}>\quad \mathrm{F}_{\mathrm{k}}, \quad \mathrm{F}_{\mathrm{n}-\mathrm{k}-1}$,

Hence, reject $\mathrm{H}_{0}$ at $\alpha=0.05$ level of significance

Thus the estimated multiple regression analysis equation for Erosion can be expressed as:

$\mathrm{Y}_{2}=1.435 \mathrm{X}+0.008 \mathrm{X}^{2}-0.0000114 \mathrm{X}^{3}$

Where: $\mathrm{Y}_{2}=$ Erosion in tons/ha

$\mathrm{X}=$ Surface Runoff in mm

\section{Interpretation:}

Value of coefficient of determination $\left(\mathrm{R}^{2}\right)$ is 0.944 , it indicates that dependency of dependent variable "erosion" is about $94.4 \%$ on runoff and remaining $5.6 \%$ is due to other variables. Hence estimated equation can be used for calculation of erosion.

\section{CONCLUSION}

ArcGIS interfaced with SWAT tool has been used for prediction and simulation of factors which are a concern for the environment. Prediction of sediment yield of the sand mining site has been explored in this study. The ArcSWAT is a convenient simulation software which has got the capability to take many environmental conditions, terrain data in the form of DEM data, land use data, soil type data etc. into account and then holistically calculate the various factors which are important from the point of view of hydrology and environment. The ArcSWAT simulation outputs are stored in the form of database and are convenient to retrieve for analysis.

This GIS based approach can be applied using Raster data with accurate sampling equipment with government agency support can provide very useful data which if judicially implemented can address many environmental problems. In spite the fact that this is quite far off from urban area and quite under exploited, the situation seems alarming [8].

The sediment yield at drainage location depends on the surface runoff of the water shed which in turn depends on the precipitation and slopes of the watershed. Based on the output results it could be clearly comprehended that the rate of replenishment of sediment yield is very less compared to the extraction and calculating safety limit doesn't seem feasible. There will always be some degradation on sand mining site.

The empirical model of sediment yield and erosion with respect to surface runoff has been worked out in the form of cubic equation with a coefficient of determination equal to 0.944. Further work on other watersheds of Rajasthan is required to check the applicability of this equation for calculation of sediment yield and erosion for given surface runoff of the area.

\section{REFERENCES}

1. Padmalal D, Maya K, Sreebha S, and Sandhya V. River sand mining and management. Report submitted to the Kerala State Council for Science, Technology and Environment, Centre for Earth Science Studies, Thiruvananthapuram 1-15, 2006.

2. Dingzhong D, and Ying T. Soil erosion and sediment yield in the Upper Yangtze River basin. IAHS Publications-Series of Proceedings and Reports-Intern Assoc Hydrological Sciences 236: 191-204, 1996.

3. Kondolf, G. M. (1994). Environmental planning in regulation and management of instream gravel mining in California. Landscape and Urban planning, 29(2-3), 185-199.

4. Chandra, P., Patel, P., Porey, P., \& Gupta, I. (2014). Estimation of sediment yield using SWAT model for Upper Tapi basin. ISH Journal of Hydraulic Engineering, 20(3), 291-300.

5. Williams J. Sediment delivery ratios determined with sediment and runoff models. IAHS Publ 122: 168-179, 1977.

6. Williams J, and Berndt $\mathrm{H}$. Sediment yield prediction based on watershed hydrology. Transactions of the ASAE 20: 1100-1104, 1977.

7. Boughton W. A review of the USDA SCS curve number method. Soil Research 27: 511-523, 1989.

8. Ojha S, and Choudhary S. Environmentally sustainable sand mining based on GIS based sediment yield estimation. Engineering and Technology in India: 49-57, Volume 8, Issue 1\&2, April \& October, 2017.

\section{AUTHORS PROFILE}

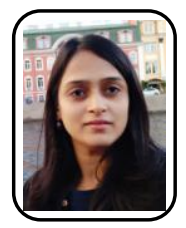

Dr. Sangeeta Choudhary

B.E in Civil Engineering. MBM Engineering College M.E. and $\mathrm{PhD}$ in Environmental Engineering from MBM Engineering College, Jodhpur

Associate Professor in Department of Civil Engineering

Techno India NJR Institute of Technology, Udaipur

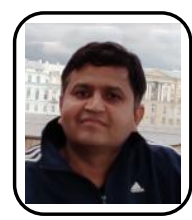

\section{Prem Choudhary}

BE in Electronics \& Communication

MSc in Telecom Technology

- Presently working as site manager in Bharat Electronics Limited in field of Satellite Communication \& OFC related projects.

Earlier worked in R \& D team of Communication a BEL Bangalore on Communication Systems of Defence 